\title{
The food intake and energy expenditure of some elderly men working in heavy and light engineering
}

\author{
By J. V. G. A. DURNIN, ELAINE C. BLAKE, MARGARET K. ALLAN, \\ ELIZABETH J. SHAW, EVELYN A. WILSON, SUSAN BLAIR \\ AND SYLVIA A. YUILL
} Institute of Physiology, University of Glasgow

(Received 8 March 1961-Revised 29 May 1961)

It is a commonplace to state that elderly people and the old are becoming an increasingly important group in the community in most countries of the world. Nutritionally, at least, it is not yet a commonplace to investigate them. Durnin, Blake, Brockway \& Drury (I96I) give the results of measurements on the food intake and energy expenditure of seventeen elderly women living alone in their separate households. The present paper describes, as part of a large-scale study on elderly people in Scotland, similar measurements on some elderly men working in three different types of engineering. Only the mean results of the study of energy expenditure are referred to briefly here; the details of the type of work and of the results obtained are given separately (Durnin \& Blake, I962).

\section{METHODS}

Measurements of the total food intake and expenditure of energy during a period of $\mathrm{I}$ week were made on thirty-three men, aged about 60 years and weighing about $70 \mathrm{~kg}$. Values for the physical characteristics of the subjects are given in Table $\mathrm{I}$. Nine of these men worked in a steel mill and were said to have one of the most physically energetic jobs in the works. Twelve men worked in a factory which made and assembled motor lorries. The remaining twelve were employed by a very large firm producing sewing machines.

Type of work. The men in the steel works were first-hand melters, i.e. they were

Table $\mathrm{x}$. Mean values, standard deviations and ranges for age, height and body-weight of three groups of elderly men

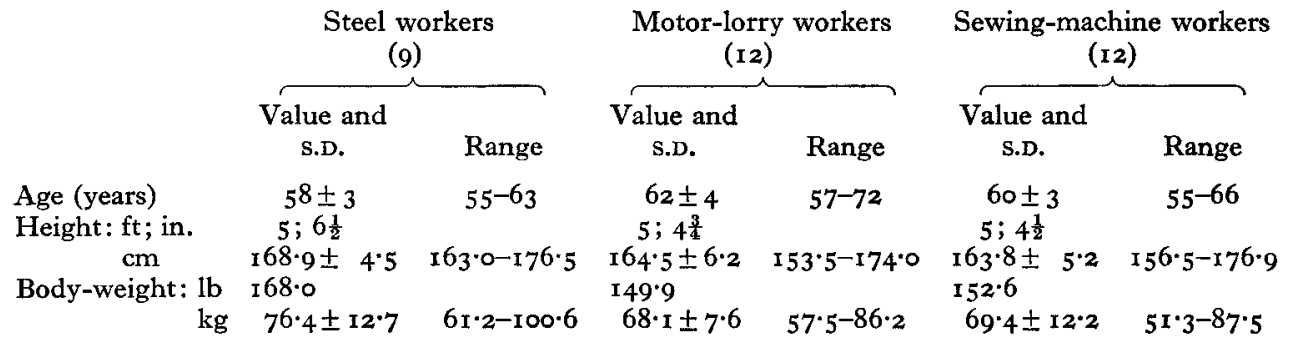

Figures in parentheses are the numbers of subjects. 
each in charge of a blast furnace which smelted the steel, and they ensured that the furnaces were kept in a good state of repair. This occupation involved occasional periods of very hard physical work shovelling large quantities of dolomite, in the form of gravel, into the furnaces, during which the men were exposed to high temperatures. The total period of this heavy labour, however, represented less than $\mathrm{I} h$ per $8 \mathrm{~h}$ shift and, during the investigation, because of a temporary recession in the steel industry, the men did only four shifts per week.

The men working in the factory assembling motor lorries undertook a variety of jobs similar to those of many industries using the conveyor-belt system. The subjects were employed in the manufacture of gear-boxes for the lorries and were skilled or semiskilled mechanics of differing types. The work was mostly done standing up and did not involve much hard physical labour.

The twelve men who worked in the sewing-machine factory did jobs of a character similar to those of the men in the factory producing motor vehicles. Again they were skilled or semi-skilled workers producing parts for the sewing-machines or inspecting and servicing the machinery. They too did little heavy physical work and most of the work during the shift was done standing at the bench, although one or two had jobs which permitted working in a sitting position.

Some of the subjects in the two light-engineering factories had a full working day which allowed little time for rest pauses; this was not, however, always so.

None of the groups differed from the others in the form of their leisure activities. A few men had cars or motor-bicycles which they cleaned occasionally and repaired; most did a variety of work in the house, from fetching coal to painting and papering. Three men worked in public houses for two or three evenings weekly. One played bowls, one did a little swimming and one played golf regularly on Sundays. The most popular leisure-time activity, however, was sitting reading or watching television.

Most of the men lived in flats or houses, usually of three rooms with kitchen and bathroom, rented from the local authority. Three men owned their houses, two owned their flats.

Measurement of energy expenditure. Energy expenditure was measured by obtaining a detailed record of the various activities of the individual men during the week of investigation and measuring the energy expenditure of the separate activities by indirect calorimetry. Total energy output for each $24 \mathrm{~h}$ day in the week was then computed by simple arithmetical calculation. Details of this method are described elsewhere (Durnin \& Brockway, I959).

Measurement of food intake. The total food intake of each subject was measured by the weighed individual-inventory method, similar to that reported by Garry, Passmore, Warnock \& Durnin (1955) and Durnin, Blake \& Brockway (1957). The separate foods were weighed and recorded just before eating and any plate wastage was similarly weighed and noted. Estimations of the nutrient value of the food consumed were made from McCance \& Widdowson's (1960) The Composition of Foods. Net calorific values of $4,9,3.75$ and 7 were assigned to protein, fat, carbohydrate and alcohol respectively. 


\section{RESULTS AND DISCUSSION}

The mean values, together with standard deviations, for energy intake and expenditure for each of the three groups of men are given in Table 2. The agreement between the intake and expenditure of calories for each of the three groups was approximately 2 , 10 and $5 \%$ respectively, which is within the range that would be expected in studies of this nature. If the values for both intake and expenditure are combined and averaged, comparison between the three groups shows that those of the men in the

Table 2. Mean values, standard deviations and ranges for daily energy intake and expenditure by three groups of elderly men

\begin{tabular}{|c|c|c|c|c|c|c|}
\hline & \multicolumn{2}{|c|}{$\begin{array}{l}\text { Steel workers } \\
\text { (9) }\end{array}$} & \multicolumn{2}{|c|}{$\begin{array}{l}\text { Motor-lorry workers } \\
\text { (12) }\end{array}$} & \multicolumn{2}{|c|}{$\begin{array}{l}\text { Sewing-machine workers } \\
\text { (12) }\end{array}$} \\
\hline & $\begin{array}{l}\text { Value and } \\
\text { S.D. }\end{array}$ & Range & $\begin{array}{l}\text { Value and } \\
\text { s.D. }\end{array}$ & Range & $\begin{array}{l}\text { Value and } \\
\text { S.D. }\end{array}$ & Range \\
\hline ntal & $3222 \pm 367$ & $2805-3963$ & $2989 \pm 322$ & $2598-3685$ & $2825 \pm 370$ & $2119-3437$ \\
\hline Expenditure (kcal) & $3276 \pm 504$ & $2598-385 I$ & $2684 \pm 3$ I 3 & $226 \mathrm{I}-3454$ & $2990 \pm 489$ & $2185-3714$ \\
\hline
\end{tabular}

Figures in parentheses are the numbers of subjects.

Values are given as calculated although the accuracy of the method warrants only results rounded off to the nearest hundred.

motor-lorry factory, about $2850 \mathrm{kcal} /$ day, and of the sewing-machine workers, about $2900 \mathrm{kcal} /$ day, were very similar. A higher result-about $3250 \mathrm{kcal} /$ day -was obtained for the steel workers, even though the amount of time they spent in very hard physical labour was only about $20 \mathrm{~min}$ a day over the whole 7 -day period. On the other hand, the mean body-weight of this group was higher than of the other two, and if the values are assessed on the basis of unit weight (e.g. $\mathrm{kcal} / \mathrm{kg}$ body-weight) they are almost identical for the three groups $(42 \cdot 8,42 \cdot 0$, and $42 \cdot 0 \mathrm{kcal} / \mathrm{kg}$ respectively).

In this particular instance there was thus little difference in the energy needs of men doing heavy work in heavy industry and those engaged in moderate work in light engineering. Whether similar results are applicable to younger men is uncertain-too few comparable groups have been studied up to the present. However, one of the social changes which might be expected from the relatively small amount of hard physical work required nowadays in heavy industry is that the total energy expended in the varying forms of industry would tend to become more uniform.

From the standpoint of calories, the most important of the foods were bread, buns, biscuits and cakes, which together contributed $34 \%$ of the mean total intake. Dairy products supplied $22 \%, 13 \%$ being from milk, cheese and eggs and $9 \%$ from butter; margarine accounted for only $2 \%$. Meat products furnished $15 \%$ of the total calories, sugar $9 \%$, puddings and breakfast cereals $4 \%$, potatoes $3 \%$, fish $2 \%$ and sweets and chocolates $2 \%$. The remaining $7 \%$ came, in small quantities, from various other items.

Table 3 shows the total calories obtained by the three groups from protein, fat, carbohydrate and alcohol, and also the proportion of the total calories derived from each of these sources. The protein intake of the steel workers was proportionately higher than that of the other groups and, at $14 \%$ of the total calories, was high by most 
standards. Because these men were considered to be heavy workers, their wives always provided ample quantities of 'good food'; one result was that their consumption of meat was twice as high as that of the other two groups. For the three groups studied, $60 \%$ of the protein eaten was of animal origin, mostly beef and milk, whereas the remaining $40 \%$ was obtained largely from bread, cakes, buns and biscuits.

The percentage of fat $(39 \%)$ in the diet was almost the same for all three groups; this figure is somewhat higher than the reported value for coal miners $(35 \%$; Garry et al. I955), but is proportionately lower than the $4 \mathrm{r} \%$ found for young adult girls, their middle-aged mothers (Durnin et al. 1957) and for elderly women (Durnin et al. 1961). Of the total fat intake, a little more than one-fifth was in the form of butter, one-fifth came from meat, one-fifth from cakes and biscuits, a little less than one-fifth from milk and cheese, and the remainder from soup, margarine, bread and other sources.

Table 3. Contribution of protein, fat, carbohydrate and alcohol to the mean daily energy value of the diets of three groups of elderly men

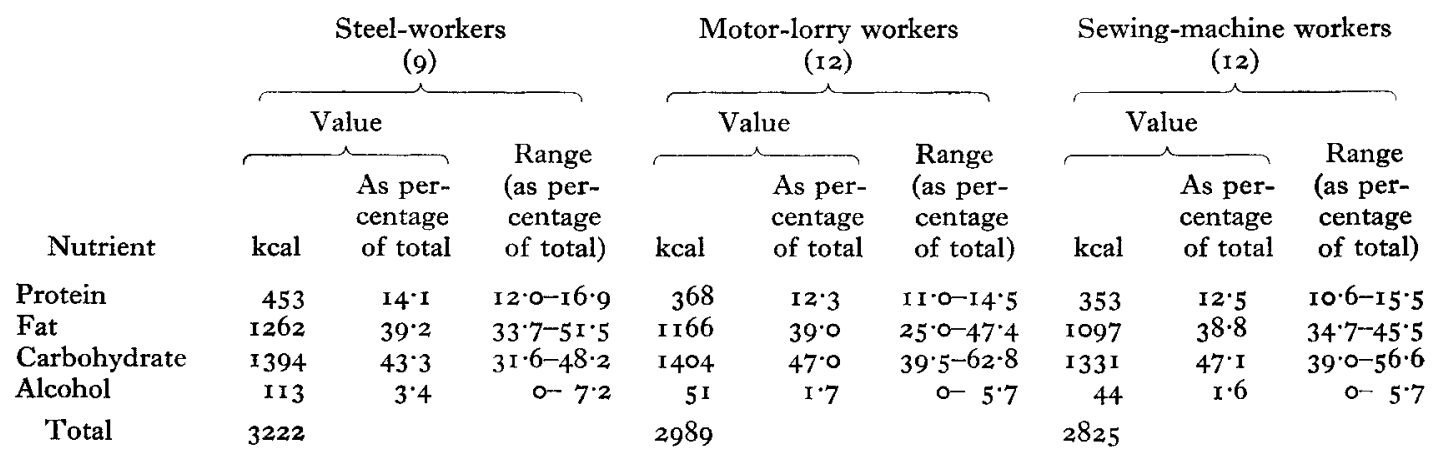

Figures in parentheses are the numbers of subjects.

Table 4. Mean values, standard deviations and ranges for intake of protein, fat, carbohydrate, calcium and iron for three groups of elderly men

\begin{tabular}{|c|c|c|c|c|c|c|}
\hline & Steel $y$ & orkers & Motor-lor & y workers & Sewing-mac & $\begin{array}{l}\text { line workers } \\
\text { 2) }\end{array}$ \\
\hline Nutrient & $\begin{array}{c}\text { Value } \\
\text { and s.D. }\end{array}$ & Range & $\begin{array}{l}\text { Value } \\
\text { and s.D. }\end{array}$ & Range & $\begin{array}{l}\text { Value } \\
\text { and s.D. }\end{array}$ & Range \\
\hline Protein (g) & $113.3 \pm 17.6$ & $85 \cdot 5^{-}$I $39 \cdot 2$ & $92 \cdot 1 \pm 10 \cdot 5$ & $71 \cdot 3-109 \cdot 2$ & $88 \cdot 2 \pm I I \cdot 8$ & $70 \cdot 6-108 \cdot 1$ \\
\hline Fat (g) & $140.2 \pm 27.5$ & $103.6-183.6$ & $129.6 \pm 29.7$ & $75 \cdot 5-174 \cdot 6$ & I $21 \cdot 9 \pm 22.5$ & $8 I \cdot 9-152 \cdot 0$ \\
\hline Carbohydrate (g) & $37 x \cdot 8 \pm 66 \cdot 9$ & $291 \cdot 6-477 \cdot 5$ & $374.5 \pm 5^{8 \cdot I}$ & $300 \cdot 5-491 \cdot 3$ & $355.0 \pm 6 I .5$ & $274.8-517.8$ \\
\hline Calcium (mg) & $1209 \pm 240$ & $770-1480$ & $1229 \pm 250$ & $932-1673$ & $948 \pm 246$ & $672-1598$ \\
\hline Iron (mg) & $18.7 \pm 3.8$ & $12.0-23.3$ & $15.9 \pm 2.3$ & $11.0-19.0$ & $16 \cdot 3 \pm 2 \cdot 4$ & $13.2-\quad 19.7$ \\
\hline
\end{tabular}

Figures in parentheses are the numbers of subjects.

Alcohol contributed more than twice as many calories for the steel workers as for the other groups. Five of the nine men drank between 6 and I I pints of beer a week; they were considered relatively abstemious. The other four steel workers and half the men in the other two groups were 'non-drinkers'. Part of the reason for the higher consumption, particularly of beer, by the 'melters' might have been the need to replace fluid loss caused by the high temperatures to which they were exposed. Large 
amounts of tea were drunk by all the men and between $\mathrm{I}$ and 2 pints of water might also be taken by the melters during a shift.

The mean total intakes, together with standard deviations, for protein, fat, carbohydrate, calcium and iron are shown in Table 4. Apart from the calcium intake by the men making sewing-machines, the results are relatively similar. No individual was remarkable for a small intake of any nutrient and, even in the group with the comparatively low calcium intake mentioned above, only one man ( $670 \mathrm{mg} /$ day) had less than $800 \mathrm{mg} /$ day. For all groups, milk and cheese provided between 40 and $50 \%$ of the total calcium, and bread, buns, cakes and biscuits about $35 \%$. However, two men managed to have intakes of 800 and $95^{\circ} \mathrm{mg}$ Ca daily, in spite of eating no cheese at all and drinking only $\frac{1}{4}$ pint of milk daily.

\section{SUMMARY}

I. Thirty-three men, aged about 60 years and weighing about $70 \mathrm{~kg}$, were investigated during a $\mathrm{I}$-week period for total food intake and energy expenditure. They worked in three industries: $(a)$ a steel-works, $(b)$ a motor-lorry assembly factory and $(c)$ a sewing-machine manufactory.

2. The mean intake and expenditure of groups $(b)$ and $(c)$ were about $2800-$ $2900 \mathrm{kcal} /$ day; the value for group (a) was about $3200 \mathrm{kcal} /$ day. However, if allowance is made for difference in body-weight, the energy values for all three groups were similar.

3. Protein contributed $12-14 \%$ of the total calories, fat about $39 \%$ and alcohol $\mathrm{I} \cdot 5-3 \cdot 5 \%$.

This investigation formed part of a large-scale survey financed by the Medical Research Council. One of the authors (J.D) was in receipt of a research grant from the Scottish Hospital Endowments Research Trust.

We are very grateful for the whole-hearted help and co-operation given by the managements, union officials and men in the three firms where these studies took place.

\section{REFEREN CES}

Durnin, J. V. G. A. \& Blake, E. C. (1962). Ergonomics. (In the Press.)

Durnin, J. V. G. A., Blake, E. C. \& Brockway, J. M. (1957). Brit. F. Nutr. Ir, 85.

Durnin, J. V. G. A., Blake, E. C., Brockway, J. M. \& Drury, E. A. (196r). Brit. F. Nutr. 15, 499.

Durnin, J. V. G. A. \& Brockway, J. M. (1959). Brit. F. Nutr. r3, 41.

Garry, R. C., Passmore, R., Warnock, G. M. \& Durnin, J. V. G. A. (1955). Spec. Rep. Ser. med. Res. Coun., Land., no. 289 .

McCance, R. A. \& Widdowson, E. M. (1960). Spec. Rep. Ser. med. Res. Coun., Lond., no. 297. 